\title{
CD58 wt Allele
}

National Cancer Institute

\section{Source}

National Cancer Institute. CD58 wt Allele. NCI Thesaurus. Code C51129.

Human CD58 wild-type allele is located within 1 p13 and is approximately $67 \mathrm{~kb}$ in length.

This allele, which encodes lymphocyte function-associated antigen 3 immunoprotein,

plays a role in adhesion and the optimization of immune recog nition. 